\title{
Microchemistry of juvenile Mercenaria mercenaria shell: implications for modeling larval dispersal
}

\author{
A. M. Cathey ${ }^{1, *}$, N. R. Miller $^{2}$, D. G. Kimmel ${ }^{3}$ \\ ${ }^{1}$ Department of Biology, East Carolina University, Greenville, North Carolina 27858, USA \\ ${ }^{2}$ Department of Geological Sciences, The University of Texas at Austin, Austin, Texas 78712, USA \\ ${ }^{3}$ Department of Biology, Institute for Coastal Science and Policy, East Carolina University, Greenville, North Carolina 27858, USA
}

\begin{abstract}
The elemental signature of trace and minor elements within biominerals has been used to investigate the larval dispersal of bivalves. We investigated the potential of this technique by examining elemental signals in juvenile shells of the hard clam Mercenaria mercenaria within an estuarine-lagoonal system near Cape Lookout, North Carolina, USA. We assessed the spatial distinction ( 12 to $40 \mathrm{~km}$ ) and temporal stability (fall versus spring) of elemental concentrations using inductively coupled plasma mass spectrometry (ICP-MS). Twelve minor and trace elements were present at detectable levels in all shell samples: calcium (Ca), manganese (Mn), aluminum $(\mathrm{Al})$, titanium $(\mathrm{Ti})$, cobalt $(\mathrm{Co})$, copper $(\mathrm{Cu})$, barium $(\mathrm{Ba})$, magnesium $(\mathrm{Mg})$, zinc $(\mathrm{Zn})$, lead $(\mathrm{Pb})$, nickel (Ni), and strontium (Sr). Discriminant function analyses (DFA) using metal to Ca ratios as independent variables correctly assigned hard clams to their site of collection with $100 \%$ success from both fall and spring sampling events. Mn:Ca ratio proved to be the most effective discriminator explaining 91.2 and $71.9 \%$ of our among-group variance, respectively. Elemental concentrations within juvenile shell differed temporally. A combined DFA approach using shell from both sampling events obtains a classification success of $81.9 \%$. Mn:Ca ratio explained the bulk of among group variance $(89.9 \%)$ and was consistently different among water masses during each season. Our results demonstrate for the first time the existence of small-scale spatial differences $(\sim 12 \mathrm{~km})$ in the elemental chemistry of juvenile bivalve shell exclusively within an estuarinelagoonal system. Our results suggest that the validation of a similar chemical signal of M. mercenaria larval shells is possible and may be used to trace the dispersal trajectory of this economically important species.
\end{abstract}

KEY WORDS: Mercenaria mercenaria - Microchemistry · Larval dispersal · Population connectivity $\cdot$ Estuary $\cdot$ Plasma mass spectrometry

\section{INTRODUCTION}

Many marine and estuarine species have an obligate period of planktonic dispersal that has significant implications for their population dynamics by directly influencing the number of potential recruits in a given area (Thorson 1950). The identification of distinct elemental signals within biogenic carbonate has emerged as technique to infer patterns of larval dispersal on temporal and spatial scales that are eco- logically significant (Thorrold et al. 2002). The primary concept of this methodology is that the composition of biominerals (e.g. otolith, larval shell) may reflect a unique chemical composition associated with the habitat in which they form (Gillanders \& Kingsford 1996, Zacherl 2005, Becker et al. 2007).

Within the mineral fraction of the biogenic carbonate matrix, the process of minor and trace element incorporation is facilitated by substitution between similar sized divalent elements such as strontium ( $\mathrm{Sr}$ ) and 
barium (Ba) among others with calcium (Ca). Smaller cations such as manganese (Mn) or magnesium $(\mathrm{Mg})$ constitute the interstitial organic fraction of the biomineral (Morrison \& Brand 1986, Takesue et al. 2008). Physiological processes are biased in favor of optimal environmental conditions and strongly influence elemental incorporation into molluscan biominerals (Stecher et al. 1996, Vander Putten et al. 2000, Carré et al. 2006). Specific food resources, particularly diatoms, may also influence elemental incorporation (Sternberg et al. 2005, Thébault et al. 2009). Additional environmental factors further contribute to this process, and evidence suggests that the incorporation of some elements may be predictably influenced by the chemical and physical characteristics of the water in which they form. Laboratory experiments have demonstrated a positive linear relationship between the concentration of $\mathrm{Mg}: \mathrm{Ca}$, lead (Pb):Ca, cerium (Ce):Ca, and $\mathrm{Ba}: \mathrm{Ca}$ ratios within molluscan biominerals and the concentration of these elements within culture water (Lorens \& Bender 1980, Lloyd et al. 2008, Zacherl et al. 2009). Variation in temperature may also influence the incorporation of trace elements within biominerals. Specifically, exothermic reactions have a negative enthalpy and are predicted to be preferred at colder temperatures. Empirical evidence supports equilibrium thermodynamic predictions by demonstrating an inverse temperature effect regarding Ba incorporation into gastropod and cephalopod statoliths (Zacherl et al. 2003, Zumholz et al. 2007). However, as suggested by Zacherl et al. (2003) and demonstrated conclusively by Lorrain et al. (2005), kinetic effects such as the precipitation rate of cations to the crystal surface may override thermodynamic predictions to further influence elemental incorporation into molluscan biominerals. Finally, interactions between multiple environmental factors can influence elemental incorporation and species-specific differences have also been reported (Swearer et al. 2003, Elsdon \& Gillanders 2004, Zumholz et al. 2007).

Elemental fingerprinting represents a powerful tool to trace patterns of invertebrate larval dispersal and population connectivity due to the potential for all larvae within a particular area to incorporate a geospatially distinct chemical signal (Thorrold et al. 2007). If habitat-specific signals exist and are temporally and spatially stable on ecologically relevant scales, the potential exists to investigate questions regarding the natal origin and dispersal trajectory of successfully recruited bivalves (Becker et al. 2007). In order to apply this methodology, determining either the chemical composition of the water in which larval biominerals are formed or the stability of elemental signals through time is necessary (Gillanders 2002, Becker et al. 2005, Dunphy et al. 2011, Fodrie et al. 2011). Additionally, the chemical signal of all potential natal origins must be investigated to accurately assess the spatial distinction of trace element incorporation into larval structures (Campana et al. 2000). Finally, provided the former assumptions are found to be true, chemical analysis of biominerals formed during larval development and retained through subsequent ontogeny is critical to reconstruct larval origin and subsequent dispersal trajectory (DiBacco \& Levin 2000). Such structures are observed in fish (otoliths), gastropods (statocyst and protoconch), and bivalves (prodissoconch) among others (Campana 1999, Zacherl et al. 2003, Zacherl 2005, Becker et al. 2007).

The first study to employ an invertebrate model with a retained larval biomineral that was formed pelagically used bivalves as a model organism (Becker et al. 2005). These authors investigated the temporal stability and spatial distinction of potential elemental signals by collecting shells of recently settled mussels Mytilus spp. Their results support a growing body of literature suggesting that trace element signals can be stable on both weekly and monthly time scales and can be used to assign individuals to specific areas at spatial scales on the order of $\sim 10$ to $30 \mathrm{~km}$ (Thorrold \& Shuttleworth 2000, Dorval et al. 2005b, Ruttenberg et al. 2008). Subsequent work by Becker and colleagues (2007) concerned questions involving patterns of mussel connectivity. The primary objective of this study was to use in situ larval culturing to determine if the distinct chemical signal observed in the shell of the post settlement stage could be validated for the larval shell of the pelagic veliger stage (Becker et al. 2007). Their research provided the first evidence that trace element analysis can be applied to bivalve larvae to determine the natal origin and dispersal trajectory of recruited individuals.

Despite limited representation in the literature, the application of trace element fingerprinting to understand patterns of invertebrate larval dispersal and population connectivity shows great promise. Here we examine its potential utility to model the larval dispersal of the obligate, estuarine invertebrate Mercenaria mercenaria, hereafter referred to as the hard clam, within the estuarine-lagoonal system near Cape Lookout, North Carolina, USA. In North Carolina, hard clams experience a protracted reproductive period that is bimodal and characterized by concentrations of spawning activity during the spring (April-June) and fall (August-October) (Peterson \& Fegley 1986). Fertilization is external, and subsequent larval development is pelagic and typified by 
the secretion of an initial larval shell known as the prodissoconch I (PDI) within $\sim 24$ to $48 \mathrm{~h}$ (Fig. 1). The retention of the PDI by recruited individuals carries the potential to provide an elemental signal from natal estuaries (Carriker 2001).

The objective of this study was to investigate the spatial distinction and temporal stability of potential elemental signals during seasonally elevated periods of larval dispersal by collecting newly recruited individuals from 4 water masses separated by at least $\sim 12 \mathrm{~km}$ during October 2010 and June 2011. Shell minor and trace chemistry was analyzed in solution using quadrapole inductively coupled plasma mass spectrometry (ICP-MS). Our goal was to determine if the trace element composition of juvenile shell was indicative of settlement habitat. If so, this result suggests that trace element signals may exist in the larval shell and may be used to determine natal habitat and dispersal trajectories. Additionally, between June and October 2010 the elemental composition of estuarine waters was analyzed quasi-monthly using inductively coupled plasma optical emission spectrometry (ICP-OES) to investigate if any observed trends were potentially facilitated by the chemical composition associated with a particular water mass. No study to date has investigated the application of elemental fingerprinting to potentially identify patterns of bivalve dispersal exclusively within an estuarine-lagoonal system. The environmental conditions within estuaries are naturally variable due to coastal geology, pollution, atmospheric deposition, and inputs from local watersheds, making them ideal systems to investigate the application of trace ele-

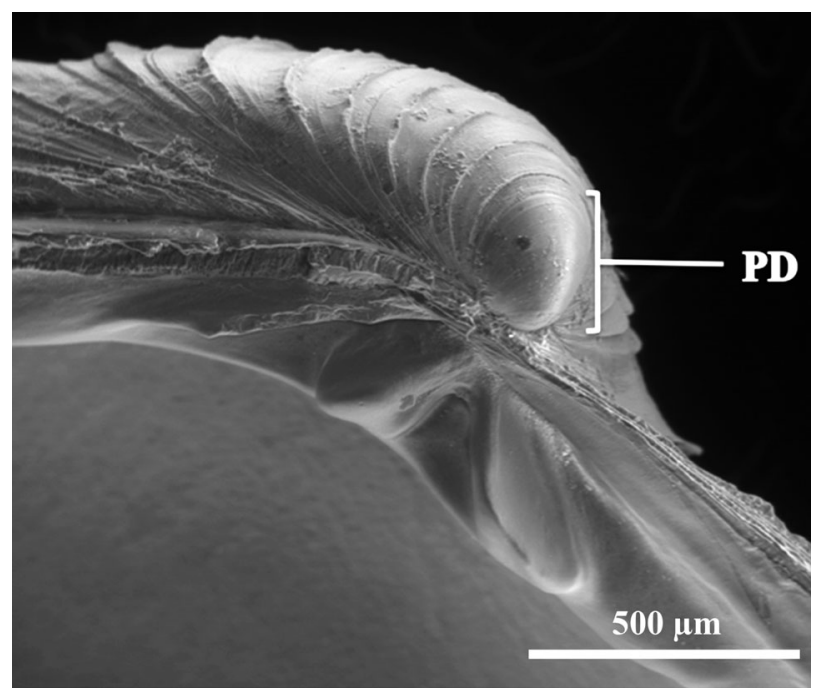

Fig. 1. Mercenaria mercenaria. Juvenile hard clam shell showing the retained larval shell, the prodissoconch (PD) ment chemistry (Swearer et al. 2003, Thorrold et al. 2007). If patterns of hard clam larval dispersal and population connectivity can be elucidated, the potential exists to identify subpopulations that may differentially contribute to overall population dynamics by disproportionately supplying larvae. This in turn could have broad implications for the management, conservation, and restoration of hard clam populations throughout their entire range.

\section{MATERIALS AND METHODS}

\section{Site selection}

Our study occurred in the Cape Lookout vicinity of the North Carolina Coast, USA, and included sites within the Newport River Estuary, North River Estuary, Back Sound, and Jarrett Bay (Fig. 2). These sites were selected because their hydrodynamic properties are such that retention of clam larvae is predicted through the formation of the PDI. The flushing time of the Newport River Estuary has been estimated to be 4 to $6 \mathrm{~d}$ (Evans et al. 1977). Additionally, a particle tracking model developed by Leuttich et al. (1999) to investigate larval transport in the vicinity of Beaufort Inlet demonstrates that a passive particle experiences diminished advection as one moves towards the heads of the associated estuaries due to increased bottom friction associated with shallow water depths, differential geomorphology, and the presence of vegetation. In these areas passive transport is estimated at $\leq 2 \mathrm{~km}$ over the course of a semi-diurnal tidal cycle. Based on these investigations and assuming larvae essentially behave as passive particles during the early stages of embryogenesis, we expect larvae to be retained within natal estuaries during the first 24 to $48 \mathrm{~h}$ of life from fertilization to the PDI stage (Carriker 2001).

\section{Sample collection}

During October 2010 and June 2011, recently settled Mercenaria mercenaria of 2 to $9.7 \mathrm{~mm}$ shell length ( 3 to $19 \mathrm{wk}$ of age as interpreted from Carriker 2001) were sampled. Recruits were collected from a single site within each of 4 water masses that are separated by $\sim 12$ to $40 \mathrm{~km}$, Newport River Estuary, North River Estuary, Jarrett Bay, and Back Sound (Fig. 2), using a PVC corer of $10 \mathrm{~cm}$ diameter and a $1 \mathrm{~mm}$ mesh sieve. After collection samples were immediately frozen in local seawater and stored at $-30^{\circ} \mathrm{C}$. 


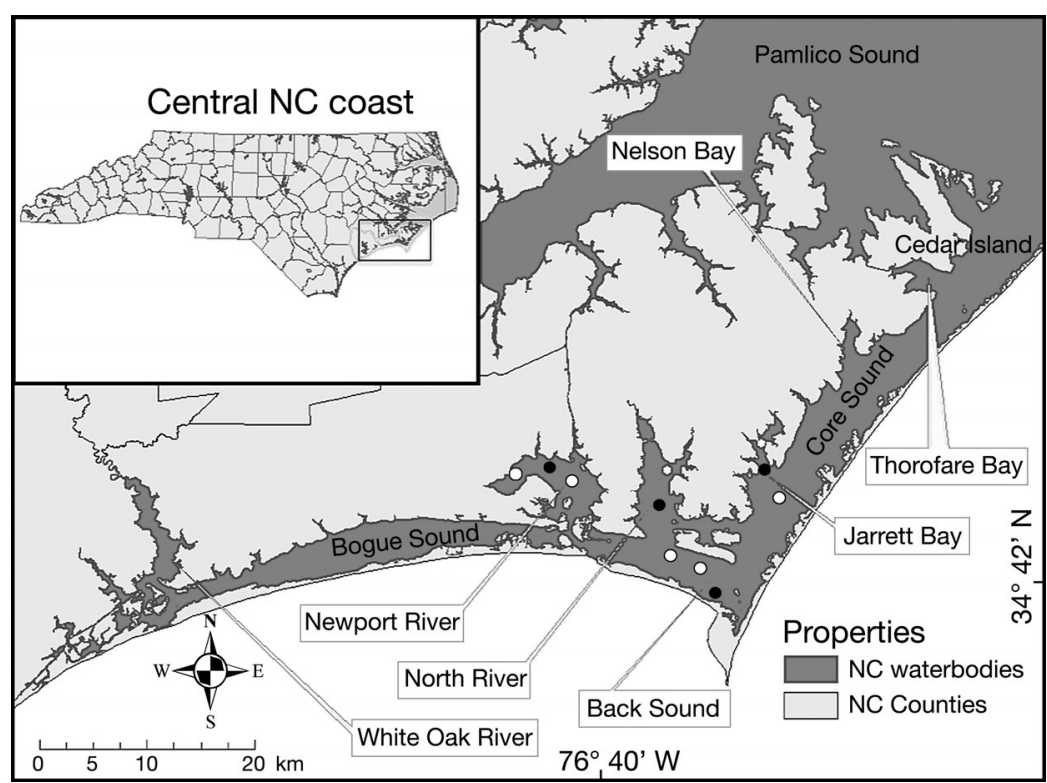

Fig. 2. Central coast of North Carolina, USA. O: area sampled for water between June and October 2010. • collection site for recruited hard clams during October 2010 and June 2011

Samples were processed in a fashion similar to that used by Zacherl (2005). The isolation of juvenile shell was conducted in a class 100 Laminar flow hood. Shell length for each clam was measured to the nearest $0.10 \mathrm{~mm}$ using an ocular micrometer and flesh was manually removed from the shell using acid washed plastic forceps $\left(7 \% \mathrm{HNO}_{3}\right.$ v/v Optima Grade; Fisherbrand) and remaining organic tissue was dissolved by submersing the shell in an equal parts mixture of $15 \% \mathrm{H}_{2} \mathrm{O}_{2}(\mathrm{v} / \mathrm{v})$ (Sigma-Aldridge) buffered in $0.1 \mathrm{~N} \mathrm{NaOH}$ (Fisherbrand) for $\sim 24 \mathrm{~h}$. Shell material was then washed 3 times with $(18.2 \Omega)$ ultrapure water, submersed in $1 \% \mathrm{HNO}_{3}$ (v/v) (Optima Grade; Fisherbrand) for $\sim 10 \mathrm{~s}$, rinsed 3 additional times with $(18.2 \Omega)$ ultrapure water, and dried under laminar flow. Once dry, the left valve of each clam was weighed to the nearest $\mathrm{mg}$. Shells were dry stored in acid-washed polypropylene vials $\left(7 \% \mathrm{HNO}_{3} \mathrm{v} / \mathrm{v}\right.$ Optima Grade; Fisherbrand) until analysis.

\section{Elemental analysis of clam shells}

Juvenile bivalve shell samples (49 single valves, each ranging from 1 to $54.5 \mathrm{mg}$; average: $5 \mathrm{mg}$ ) were placed in acid-cleaned polypropylene microvials and reacted in $1 \mathrm{ml}$ of $2 \% \mathrm{HNO}_{3}(\mathrm{v} / \mathrm{v})$ or $5 \% \mathrm{HNO}_{3}(\mathrm{v} / \mathrm{v})$ over $24 \mathrm{~h}$ until complete dissolution occurred. The acid was made from Fisher trace metal grade $\mathrm{HNO}_{3}$ (70\%; Lot 1107120) and Type 1 (18.2 $\Omega$ ) ultrapure wa- ter. Following centrifugation (5 min at $11000 \mathrm{rpm}$ ), bivalve leachate aliquots were transferred to acid-cleaned polypropylene tubes and further diluted in $2 \% \mathrm{HNO}_{3}(\mathrm{v} / \mathrm{v})$ to obtain final dilution factors appropriate for trace-minor (2000 to 2500x) and major element (Ca: $40000 \times$ ) determinations.

Samples were analyzed for major, minor, and trace elements, in 2 analytical sessions, on an Agilent 7500ce ICP-MS. We surveyed 34 elements: boron (B), sodium $(\mathrm{Na}), \mathrm{Mg}$, aluminum $(\mathrm{Al})$, silicon $(\mathrm{Si})$, phosphorus $(\mathrm{P})$, potassium $(\mathrm{K}), \mathrm{Ca}$, titanium $(\mathrm{Ti})$, vanadium $(\mathrm{V})$, chromium $(\mathrm{Cr}), \mathrm{Mn}$, iron $(\mathrm{Fe})$, cobalt $(\mathrm{Co})$, nickel $(\mathrm{Ni})$, copper $(\mathrm{Cu})$, zinc $(\mathrm{Zn})$, arsenic $(\mathrm{As})$, selenium $(\mathrm{Se})$, rubidium $(\mathrm{Rb}), \mathrm{Sr}$, zirconium (Zr), molybdenum (Mo), silver (Ag), cadium (Cd), tin (Sn), antimony (Sb), caesium (Cs), $\mathrm{Ba}$, thallium (Tl), $\mathrm{Pb} \quad\left({ }^{206} \mathrm{~Pb}+{ }^{207} \mathrm{~Pb}+\right.$ $\left.{ }^{208} \mathrm{~Pb}\right)$, bismuth $(\mathrm{Bi})$, thorium $(\mathrm{Th})$, and uranium $(\mathrm{U})$, and 51 isotopes. Operating conditions were: $1500 \mathrm{~W}$ forward RF power, $1 \mathrm{~W}$ reflected RF power, $151 \mathrm{~min}^{-1}$ plasma gas flow, $0.9 \mathrm{l} \mathrm{min}^{-1}$ auxiliary gas flow, $0.9 \mathrm{l}$ $\mathrm{min}^{-1}$ carrier gas flow, $0.21 \mathrm{~min}^{-1}$ make-up gas flow, $2^{\circ} \mathrm{C}$ spray chamber temperature, and $0.1 \mathrm{rpm}$ peristaltic pump speed. Prior to quantitative analysis, the instrument was tuned to optimize sensitivity across the mass range and normalize linearity for pulse and analog counting modes of the electron multiplier. Oxide production and doubly charged species, respectively monitored from mass ratios 156/140 (CeO/Ce) and $140 / 70\left(\mathrm{Ce}^{2+} / \mathrm{Ce}^{+}\right)$, were $<2 \%$ for all runs. Spectral interferences were removed using a collision/reaction cell (Octopol Reaction System ${ }^{\circledR}$ ) by kinetic energy discrimination, using helium as the collision gas $\left({ }^{39} \mathrm{~K},{ }^{51} \mathrm{~V},{ }^{52} \mathrm{Cr},{ }^{53} \mathrm{Cr},{ }^{75} \mathrm{As}\right)$, or by mass discrimination, using hydrogen as the reaction gas $\left({ }^{28} \mathrm{Si}^{4}{ }^{40} \mathrm{Ca}_{1}{ }^{56} \mathrm{Fe}\right.$, ${ }^{78} \mathrm{Se}$ ). Reported concentrations represent the average of 3 separate analyte $\mathrm{m} / \mathrm{z}$ scans of the quadrupole. Calibration standards, made gravimetrically from multi- and single-element standards (VHG Labs) certified for concentration and density, typically obtained linear regression correlation coefficients $\mathrm{r}^{2}>0.9999$.

Trace element detection limits (1 SD), calculated from the population of blank, $2 \% \mathrm{HNO}_{3}(\mathrm{v} / \mathrm{v})$, replicates interspersed throughout the analytical sequence were typically better than $0.260 \mathrm{ppb}$ (median: $0.015 \mathrm{ppb}$ ). Accuracy and precision were evaluated from 3 quality control (QC) standards, also inter- 
spersed throughout the analytical sequence. QC1 was a lab fortified matrix spike made from the same stocks as used for calibration standards, with analyte concentrations near the middle of the calibration range. QC2 was an equivalent concentration standard but made from stocks sourced independently from the calibration standards. QC3 was National Institute of Standards and Technology (NIST) 1643e (trace elements in water). Recoveries among optimal analyte isotopes for these QC samples averaged $99.32 \pm 2.9 \%$ (mean $\pm \mathrm{SD}$ ). Relative standard deviations (1SD) from the mean among QC replicates were $<1 \%$ for QC1 and QC2, and $<4 \%$ for QC3 (certified analytes).

Despite the cleaning of biominerals with $\mathrm{H}_{2} \mathrm{O}_{2}$ before elemental analysis being widely reported in the literature, no studies investigated potential cleaning artifacts associated with this technique (Swearer et al. 2003, Becker et al. 2005, Zacherl 2005, Lloyd et al. 2008, Dunphy et al. 2011). Importantly, recent work by Krause-Nehring et al. (2011) demonstrates that treatment of biogenic carbonate with (31\%) $\mathrm{H}_{2} \mathrm{O}_{2}$ influences the elemental concentrations present. This is problematic for the interpretation of investigations concerning the chemical composition of biominerals that have been cleaned with $\mathrm{H}_{2} \mathrm{O}_{2}$. However, given that in the current study all samples were treated with a weaker $(15 \%) \mathrm{H}_{2} \mathrm{O}_{2}$ solution and in an identical fashion, we can assume that any potential artifacts will be reduced and equally distributed. Additionally, the high precision of the ICPMS analysis allows us to assume that even though our measurements likely do not accurately reflect the chemical composition of shell material before it was cleaned, the differences observed among sampling locations should not be compromised. Finally, the potential for cleaning artifacts in the present study underscores that the comparison of trace elements within clam shell with those of the ambient waters in which it formed must be taken with caution. Future work will be critical to investigate the extent of artifacts associated with the cleaning of biominerals with dilute $\mathrm{H}_{2} \mathrm{O}_{2}$.

\section{Collection of water and trace element analysis}

Between June and October 2010, we examined the spatial distinction and temporal stability of elemental signatures within ambient estuarine waters by designating 2 to 3 sampling sites in each of the 4 aforementioned water masses. Sites separated by $\sim 3 \mathrm{~km}$ along the length of each body of water were sampled to investigate potential spatial differences at local scales (Fig. 2). Water samples were collected quasimonthly on a single day using the methodology of Mohan et al. (2012). At each sampling site 2 sub-surface samples were collected at $\sim 20 \mathrm{~cm}$ depth using a Masterflex peristaltic pump and filtered inline using Whatman glass micofibre filters (GF/D $1.5 \mu \mathrm{m}$ and $0.7 \mathrm{GF} / \mathrm{F} \mu \mathrm{m})$. Samples were collected in acidwashed $\left(7 \% \mathrm{HNO}_{3}\right.$ v/v $\mathrm{HNO}_{3}$ Optima Grade; Fisherbrand) high-density fluorinated Nalgene bottles, rinsed with 3 sample volumes. Samples were stored on ice, transported to the laboratory on the date of collection and acidified to $\mathrm{pH}<2.0$ using trace element grade $70 \% \mathrm{HNO}_{3}$ (v/v) (Optima Grade; Fisherbrand). Prior to analysis, samples were filtered through $0.2 \mu \mathrm{m}$ Supor syringe filters to remove particulate fractions while keeping colloidal and dissolved fractions. All water samples were stored at $6^{\circ} \mathrm{C}$ until analysis. Environmental characteristics including: temperature, salinity, and $\mathrm{pH}$ were collected in concurrence with water using a YSI-85.

The trace element concentration of ambient waters from each sampling site was determined using the methodology of Mohan et al. (2012). Inductively coupled plasma optical emission spectrometry (ICP-OES model: Perkins-Elmer - Optima 2100 DV) was used to measure elemental concentrations of $\mathrm{Ca}, \mathrm{Mg}, \mathrm{Sr}$, $\mathrm{Ba}$, and Mn. Samples were diluted with 100 parts of ultrapure water (18.5 $\Omega$ ) to 1 part of sample. A stock standard solution $\left(10000 \mathrm{mg} \mathrm{l}^{-1}\right.$ in $2 \% \mathrm{HNO}_{3}$, Across Organics) for each element was diluted to create an element-specific calibration curve with 5 standards (lowest low, low, medium, high, and highest high). The combined stock solution was analyzed before sample analysis to produce regression correlation coefficients $\mathrm{r}^{2}>0.9999$ for all elements. Typically trace element detection limits (1SD), calculated from blank $\left(2 \% \mathrm{HNO}_{3} \mathrm{v} / \mathrm{v}\right.$, Optima Grade; Fisherbrand) replicates interspersed throughout the analytical sequence were $<5.0 \mathrm{ppb}$. Two replicate field and lab blanks consisting of ultrapure water $(18.5 \Omega)$ from each sampling date were processed and analyzed in concurrence with environmental samples. Quality control checks consisting of the low, medium, and high calibration standards required $>90 \%$ recovery and were issued after every 12 samples.

\section{Statistical analysis}

When assumptions of normality and homoscedasticity were met, analysis of variance (ANOVA) was used to investigate differences in the mean concen- 
tration of the metal:calcium ratio (hereafter Me:Ca) within juvenile shell among sampling locations for each sampling date. When these assumptions were not met, non-parametric Kruskal-Wallis tests were used. Similarly, $t$-tests and Mann-Whitney $U$-tests were used to investigate differences in the Me:Ca of juvenile shell from individual water masses between sampling dates. Discriminant function analysis (DFA) was employed to investigate the ability to classify juvenile clams to their individual site of collection. DFA is a multivariate statistical test used to produce a predictive model composed of discriminant functions derived from linear combinations of the independent variables (Me:Ca of juvenile shell) that provide the best discrimination among our dependent variables (water mass of collection) (Manly 2005). Two-factor ANOVA was used to test if the concentration of $\mathrm{Mg}, \mathrm{Ca}$, and $\mathrm{Sr}$ in ambient estuarine waters is influenced by region, time, and their interaction. Region is defined as the Newport River compared to all other water masses (North River, Jarrett Bay, Back Sound).

\section{RESULTS}

\section{Clam shell length}

No significant difference was detected in the mean shell length of recruited clams among water bodies for samples from October 12, 2011 (ANOVA: $F_{3,21}=$ $0.320, p=0.811$ ). Similarly, no significant differences were observed in the mean shell length among water bodies for samples from 23 June 2011 (KruskalWallis: $\chi^{2}=3.15, \mathrm{p}>0.05$ ). Significant differences were detected in shell length between sampling dates ( $t$-test: $t_{47}=-3.62, \mathrm{p}=0.001$ ) with larger clams being observed in the spring.

\section{Spatial distinction of elemental fingerprints}

Of 34 elements investigated, 12 were present in juvenile shell carbonate at detectable levels on each sampling date (spring and fall) (Table 1). For juvenile hard clams sampled from October 12, 2010, ANOVA revealed significant differences in $\mathrm{Mg}: \mathrm{Ca}$ among sampling locations $(\mathrm{p}<0.01)$ and Kruskal-Wallis tests revealed significant differences in the means of $\mathrm{Ba}: \mathrm{Ca}$ and $\mathrm{Mn}: \mathrm{Ca}$ among sampling locations ( $\mathrm{p}<$ 0.05). Using DFA with $\mathrm{Mn}: \mathrm{Ca}, \mathrm{Al}: \mathrm{Ca}, \mathrm{Ti}: \mathrm{Ca}, \mathrm{Co}: \mathrm{Ca}$, $\mathrm{Cu}: \mathrm{Ca}, \mathrm{Ba}: \mathrm{Ca}, \mathrm{Mg}: \mathrm{Ca}$, Zn:Ca, Pb:Ca, Ni:Ca, and $\mathrm{Sr}: \mathrm{Ca}$ serving as independent variables, juvenile

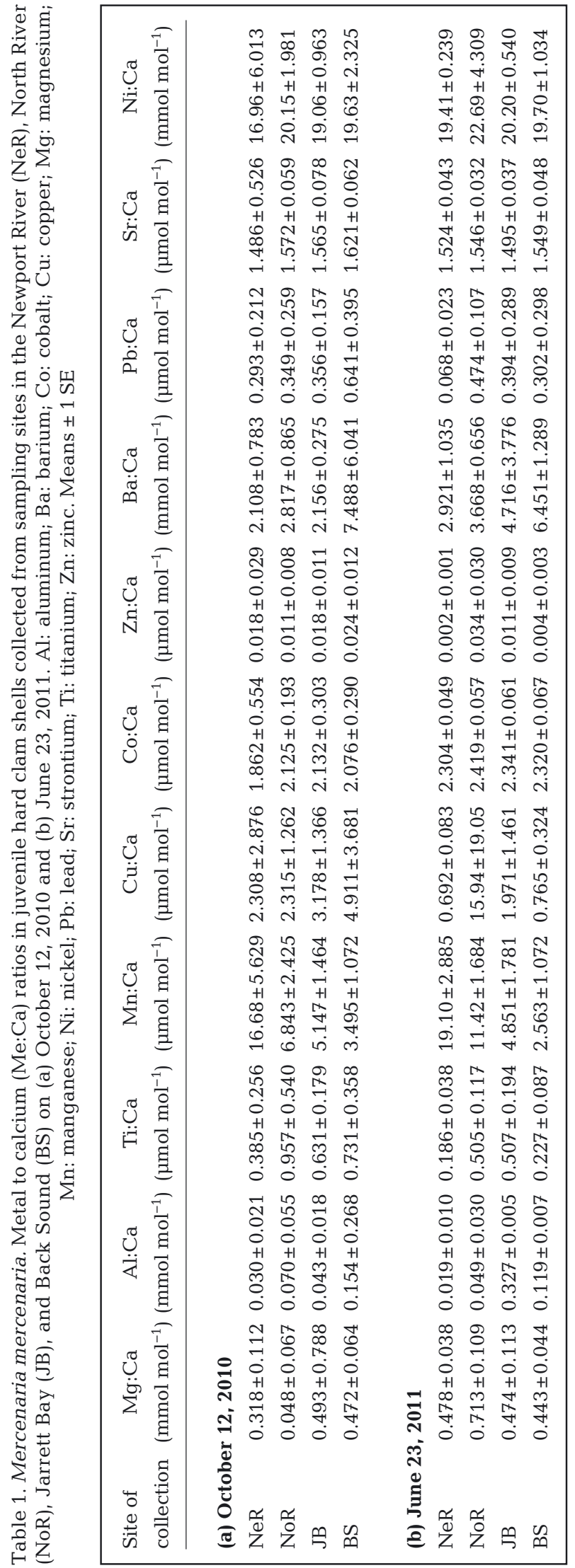


clams were assigned to their water mass of collection with $100 \%$ success (Fig. 3a, Table 2). Mn was the primary driver, responsible for $90.9 \%$ of the observed variance among water masses.

For juvenile hard clams sampled from June 23, 2011, ANOVA revealed significant differences in $\mathrm{Mg}: \mathrm{Ca}, \mathrm{Ti}: \mathrm{Ca}, \mathrm{Mn}: \mathrm{Ca}$, and Co:Ca among sampling locations $(p<0.05)$ and Kruskal-Wallis $(p<0.05)$ tests revealed significant differences in the means of $\mathrm{Ba}: \mathrm{Ca}, \mathrm{Pb}: \mathrm{Ca}, \mathrm{Zn}: \mathrm{Ca}, \mathrm{Cu}: \mathrm{Ca}$, and $\mathrm{Al}: \mathrm{Ca}$ among sampling locations. DFA with Mn:Ca, Al:Ca, Ti:Ca, $\mathrm{Co}: \mathrm{Ca}, \mathrm{Cu}: \mathrm{Ca}, \mathrm{Ba}: \mathrm{Ca}$, Mg:Ca, Zn:Ca, Pb:Ca, Ni:Ca, and $\mathrm{Sr}$ :Ca serving as independent variables once again assigned juvenile clams to their water mass of collection with $100 \%$ success (Fig. 3b, Table 3). Similar to the trends observed in October, Mn:Ca provided the bulk of the discriminating power and was responsible for $71.9 \%$ of the variance among water masses. The reduced contribution of $\mathrm{Mn}: \mathrm{Ca}$ is influenced by the increase in the number of statistically different elements among sampling sites during June sampling.

\section{Temporal stability of elemental fingerprints}

Significant temporal differences were detected in the Me:Ca of juvenile clam shells in all water masses of investigation. In Back Sound, significant decreases of Ti:Ca, Cu:Ca, and Zn:Ca (Mann-Whitney U: p < 0.05) were observed between October 2010 and June 2011. Jarrett Bay saw a significant increase in $\mathrm{Ni}: \mathrm{Ca}$ (ANOVA: $\mathrm{p}<0.05$ ) during this period. The North River experienced increases in $\mathrm{Mg}: \mathrm{Ca}, \mathrm{Mn}: \mathrm{Ca}$, and Co:Ca (ANOVA: $\mathrm{p}<0.05$ ) during the same interval. Finally, in the Newport River Mg:Ca was significantly elevated (ANOVA: $\mathrm{p}<0.05$ ) in the spring compared to the fall, while $\mathrm{Pb}: \mathrm{Ca}$ experienced a significant reduction (ANOVA: $\mathrm{p}<0.05$ ).

Despite a larger suite of elements experiencing significant differences among water masses in the spring relative to the fall, DFA was $100 \%$ successful in assigning juvenile clams to their water mass of collection on each sampling date. A combined DFA using Me:Ca from both fall and spring sampling revealed a reduction in classification success to $81.9 \%$ (Fig. 3c, Table 4). Mn:Ca was responsible for $89.9 \%$ of the among-group variance and only differed significantly in the North River between sampling dates. These data suggest that in our area of investigation, a reproducible elemental signal that is driven predominately by $\mathrm{Mn}: \mathrm{Ca}$ exists in hard clam juvenile shell (Fig. 4).
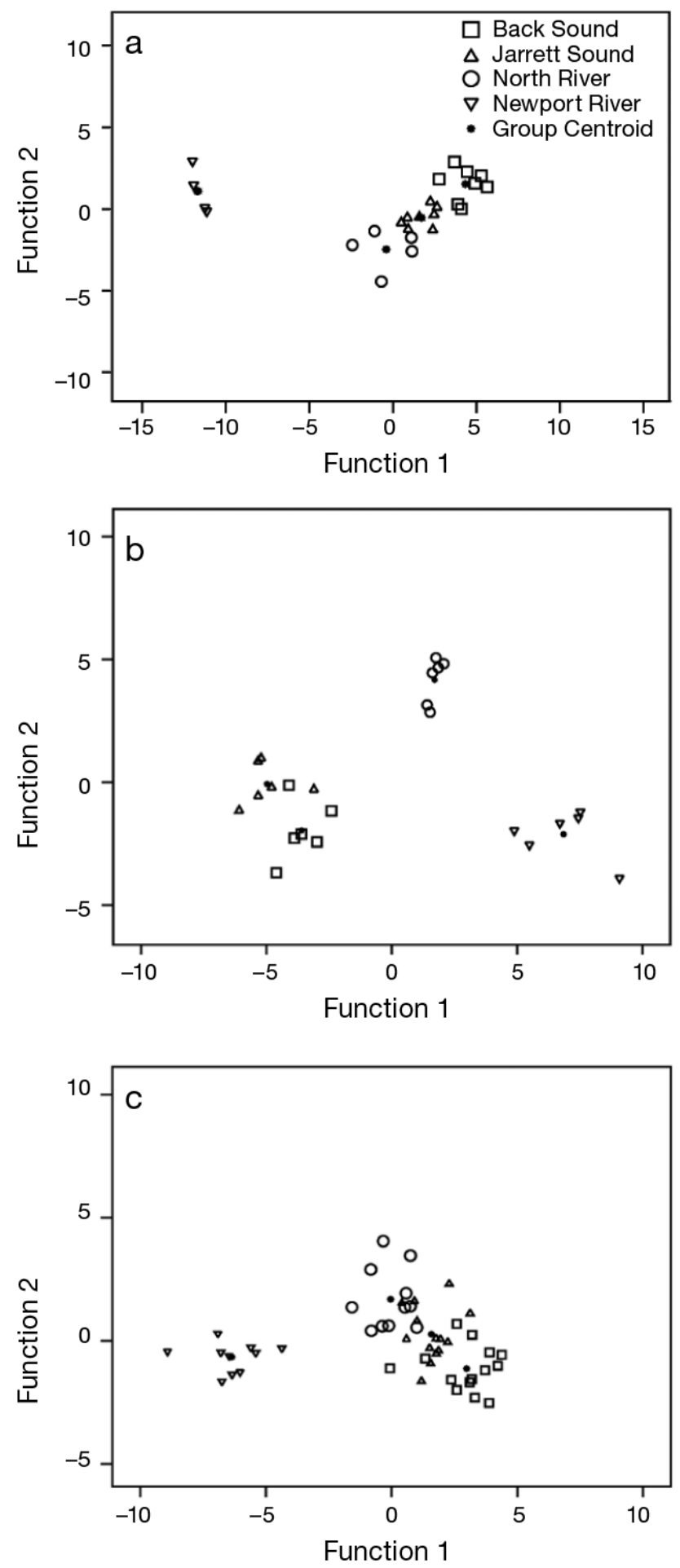

Fig. 3. Mercenaria mercenaria. Discriminant function analysis (DFA) scores of element [manganese (Mn), aluminum $(\mathrm{Al})$, titanium $(\mathrm{Ti})$, cobalt $(\mathrm{Co})$, copper $(\mathrm{Cu})$, barium $(\mathrm{Ba})$, magnesium $(\mathrm{Mg})$, zinc $(\mathrm{Zn})$, lead $(\mathrm{Pb})$, nickel $(\mathrm{Ni})$, and strontium (Sr)] to calcium $(\mathrm{Ca})$ ratios in shells of hard clam recruits collected during (A) October 2010, (B) June 2011, and (C) both October 2010 and June 2011. All scores are grouped according to water mass of collection 
Table 2. Mercenaria mercenaria. Classification success using shell microchemistry to determine the water mass of collection for juvenile hard clams collected in October 2010. Water masses grouped as Newport River, North River, Jarrett Bay, and Back Sound. Rows denote actual grouping using discriminant function analysis (DFA) model

\begin{tabular}{|lccccc|}
\hline Water mass & $\begin{array}{c}\text { Back } \\
\text { Sound }\end{array}$ & $\begin{array}{c}\text { Jarrett } \\
\text { Bay }\end{array}$ & $\begin{array}{c}\text { North } \\
\text { River }\end{array}$ & $\begin{array}{c}\text { Newport } \\
\text { River }\end{array}$ & Total \\
\hline (a) Count (no. of clams) & & & & \\
Back Sound & 8 & 0 & 0 & 0 & 8 \\
Jarrett Bay & 0 & 8 & 0 & 0 & 8 \\
North River & 0 & 0 & 5 & 0 & 5 \\
Newport River & 0 & 0 & 0 & 4 & 4 \\
(b) Correct classifications (\%) & & & \\
Back Sound & 100.0 & 0.0 & 0.0 & 0.0 & 100.0 \\
Jarrett Bay & 0.0 & 100.0 & 0.0 & 0.0 & 100.0 \\
North River & 0.0 & 0.0 & 100.0 & 0.0 & 100.0 \\
Newport River & 0.0 & 0.0 & 0.0 & 100.0 & 100.0 \\
\hline
\end{tabular}

Table 3. Mercenaria mercenaria. Classification success using shell microchemistry to determine the water mass of collection for juvenile hard clams collected in June 2011. For details see Table 2 legend

\begin{tabular}{|lccccc|}
\hline Water mass & $\begin{array}{c}\text { Back } \\
\text { Sound }\end{array}$ & $\begin{array}{c}\text { Jarrett } \\
\text { Bay }\end{array}$ & $\begin{array}{c}\text { North } \\
\text { River }\end{array}$ & $\begin{array}{c}\text { Newport } \\
\text { River }\end{array}$ & Total \\
\hline (a) Count (no. of clams) & & & & \\
Back Sound & 6 & 0 & 0 & 0 & 6 \\
Jarrett Bay & 0 & 6 & 0 & 0 & 6 \\
North River & 0 & 0 & 6 & 0 & 6 \\
Newport River & 0 & 0 & 0 & 6 & 6 \\
(b) Correct classifications (\%) & & & \\
Back Sound & 100.0 & 0.0 & 0.0 & 0.0 & 100.0 \\
Jarrett Bay & 0.0 & 100.0 & 0.0 & 0.0 & 100.0 \\
North River & 0.0 & 0.0 & 100.0 & 0.0 & 100.0 \\
Newport River & 0.0 & 0.0 & 0.0 & 100.0 & 100.0 \\
\hline
\end{tabular}

Table 4. Mercenaria mercenaria. Classification success using shell microchemistry to determine the water mass of collection for juvenile hard clams from both October 2010 and June 2011. For details see Table 2 legend

\begin{tabular}{|lccccc|}
\hline Water mass & $\begin{array}{c}\text { Back } \\
\text { Sound }\end{array}$ & $\begin{array}{c}\text { Jarrett } \\
\text { Bay }\end{array}$ & $\begin{array}{c}\text { North } \\
\text { River }\end{array}$ & $\begin{array}{c}\text { Newport } \\
\text { River }\end{array}$ & Total \\
\hline (a) Count (no. of clams) & & & & \\
Back Sound & 10 & 4 & 0 & 0 & 14 \\
Jarrett Bay & 2 & 10 & 2 & 0 & 14 \\
North River & 0 & 1 & 10 & 0 & 11 \\
Newport River & 0 & 0 & 0 & 10 & 10 \\
(b) Correct classifications (\%) & & & \\
Back Sound & 71.4 & 28.6 & 0.0 & 0.0 & 100.0 \\
Jarrett Bay & 14.3 & 71.4 & 14.3 & 0.0 & 100.0 \\
North River & 0.0 & 9.1 & 90.9 & 0.0 & 100.0 \\
Newport River & 0.0 & 0.0 & 0.0 & 100.0 & 100.0 \\
\hline
\end{tabular}

\section{Elemental content of estuarine waters}

Of the 5 elements investigated, $\mathrm{Sr}, \mathrm{Mg}, \mathrm{Ca}$, and $\mathrm{Ba}$ were present at detectable levels, and Mn was below limits of detection on all sampling dates. ANOVA revealed significant effects of month, region, and an interaction between month and region regarding the concentration of $\mathrm{Sr}, \mathrm{Mg}$, and Ca ( $<$ < 0.001) (Table 5). The concentration of $\mathrm{Sr}, \mathrm{Mg}$, and $\mathrm{Ca}$ did not differ significantly between the North River, Back Sound, and Jarrett Bay on all sampling dates. Concentrations of these elements covaried with salinity and were significantly reduced in the Newport River compared to all other water masses on most sampling dates (Fig. 5a-d). A relationship with salinity is further evidenced by their shared conservative behaviors along the salinity gradient (Fig. 6a-c). Ba varied spatially and was observed to be elevated in the Newport River in June compared to all other areas of investigation. Ba also differed temporally and was observed to increase from June to August in all water masses, remain below the limits of detection in September, and exhibit a pronounced reduction in October compared to all previous sampling dates (Fig. 5e).

\section{DISCUSSION}

\section{Spatial variation of elemental fingerprints}

Our results demonstrate that distinct elemental signals exist in hard clam juvenile shell and are detectable at small spatial scales $(\sim 12 \mathrm{~km})$ (Fig. 3a,b, Tables 2 \& 3). Our results further suggest that elemental signals are likely to exist in larval shell (PDI) that is produced over the first 24 to $48 \mathrm{~h}$ of a clam's life and may be used to indicate natal origin. $\mathrm{Mn}, \mathrm{Ba}$, and $\mathrm{Mg}$ were the only elements present in juvenile shell that differed significantly among water masses on both sampling dates. DFA revealed that Mn was the primary component of the elemental signal that explained the bulk of among-site variance during both fall (91.2\%) and spring $(71.9 \%)$. The observed contribution of $\mathrm{Mn}$ is not unexpected as this element has been used to help discriminate the natal origin or site of collection for crab zoea, juvenile bivalves, pelagic bivalve veligers, and encapsulated gastropod veligers (DiBacco \& Levin 2000, Becker et al. 2005, 2007, Zacherl 2005, Dunphy et al. 2011).

In estuarine systems, $\mathrm{Mn}$ is delivered via fluvial inputs and the reduction and solubilization of $\mathrm{MnO}_{2}$ within anoxic sediments (Evans et al. 1977). Once dissolved Mn has been delivered or released into 

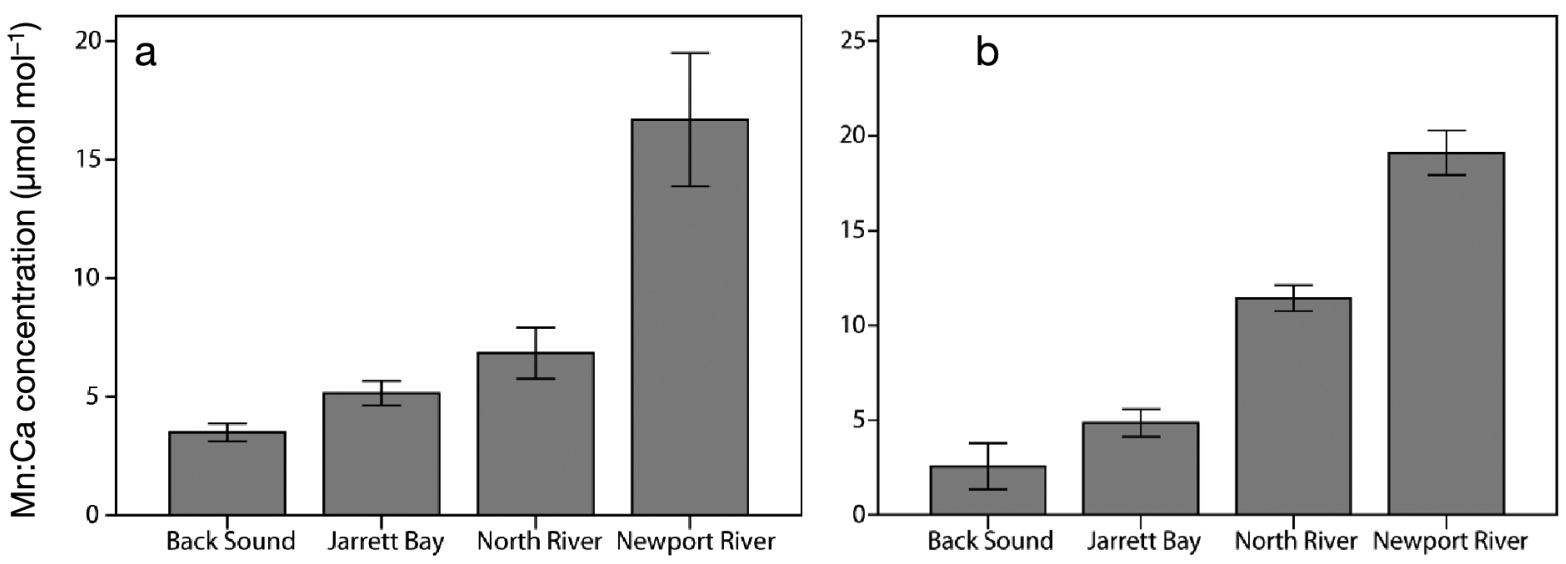

Water mass

Fig. 4. Mercenaria mercenaria. Concentration of manganese to calcium (Mn:Ca) ratio within the shells of recruited hard clams collected from each water mass during (a) October 2010 and (b) June 2011. Means \pm SE

the water column it has been reported to behave both conservatively and non-conservatively along the estuarine salinity gradient (Evans et al. 1977, Morris et al. 1982, Dorval et al. 2005a). Unfortunately, Mn was below the limits of detection in sampled estuarine waters, preventing a direct comparison with salinity or concentrations within juvenile shell. This limitation is further compounded by elevated $\mathrm{Mn}$ concentrations in muddy sediments within our study area compared to the overlying water column (Evans et al. 1977). This complicates the assumption that hard clam larval shell will reflect the Mn signal observed in juvenile shell due to a decreased proximity to the sediment-water interface. However, in the current study, juvenile clams were collected from sandy habitats where metal

Table 5. Two factor analysis of variance (ANOVA) testing if the concentration of magnesium $(\mathrm{Mg})$, calcium $(\mathrm{Ca})$, and strontium $(\mathrm{Sr})$ in ambient estuarine waters is influenced by region, time, and their interaction. Region is defined as the Newport River compared to all other water masses (North River, Jarrett Bay, Back Sound)

\begin{tabular}{|ccccccc|}
\hline Source & $\begin{array}{c}\text { Dependent } \\
\text { variable }\end{array}$ & $\begin{array}{c}\text { Type III sum } \\
\text { of squares }\end{array}$ & df & MS & $F$ & $\mathrm{p}$ \\
\hline Region & $\mathrm{Sr}$ & 14.1 & 1 & 14.1 & 35.8 & 0.000 \\
& $\mathrm{Mg}$ & 824973.9 & 1 & 824973.9 & 31.0 & 0.000 \\
& $\mathrm{Ca}$ & 49188.3 & 1 & 49188.3 & 35.2 & 0.000 \\
Month & $\mathrm{Sr}$ & 61.3 & 4 & 15.3 & 38.9 & 0.000 \\
& $\mathrm{Mg}$ & 3.7 & 4 & 932004.0 & 35.1 & 0.000 \\
& $\mathrm{Ca}$ & 155728.4 & 4 & 38932.1 & 27.9 & 0.000 \\
Region $\times$ & $\mathrm{Sr}$ & 8.5 & 4 & 2.1 & 5.4 & 0.001 \\
Month & $\mathrm{Mg}$ & 509238.9 & 4 & 4.8 & 4.8 & 0.001 \\
& $\mathrm{Ca}$ & 29443.2 & 4 & 5.3 & 5.3 & 0.001 \\
\hline
\end{tabular}

entrainment is minimal compared to fine sediments (George et al. 2007). Riggs et al. (1991) investigated sediment Mn concentrations associated with various substrate types within an estuarine system adjacent to our study area (Neuse River Estuary). Data obtained from this investigation demonstrate that Mn is reduced substantially in substrate that is predominately sand (Fig. 7). Work by Zacherl et al. (2009) demonstrates a positive linear relationship that acts independently of ontogeny between $\mathrm{Mn}$ concentration in culture water and incorporation into larval and juvenile shell of the Olympic oyster Ostrea lurida. If the incorporation of $\mathrm{Mn}$ into hard clam carbonate also operates independently of ontogeny, the distinct Mn signal observed in juvenile shell may also be present in the larval form.

Ba has also been successfully employed to help discriminate the natal origin or site of collection for multiple invertebrate models (DiBacco \& Levin 2000, Becker et al. 2005, 2007, Zacherl 2005, Dunphy et al. 2011). The delivery of Ba into estuarine systems is driven predominately by fluvial inputs and is reported to mix conservatively along the estuarine salinity gradient (Coffey et al. 1997, Dorval et al. 2005a). Within our study area dissolved $\mathrm{Ba}$ is proportional to salinity (Fig. 6d). Studies have demonstrated a positive linear relationship between the Ba content of culture water and incorporation into invertebrate biominerals (Gillikin et al. 2006, Zacherl et al. 2003, 2009). However, the Ba 

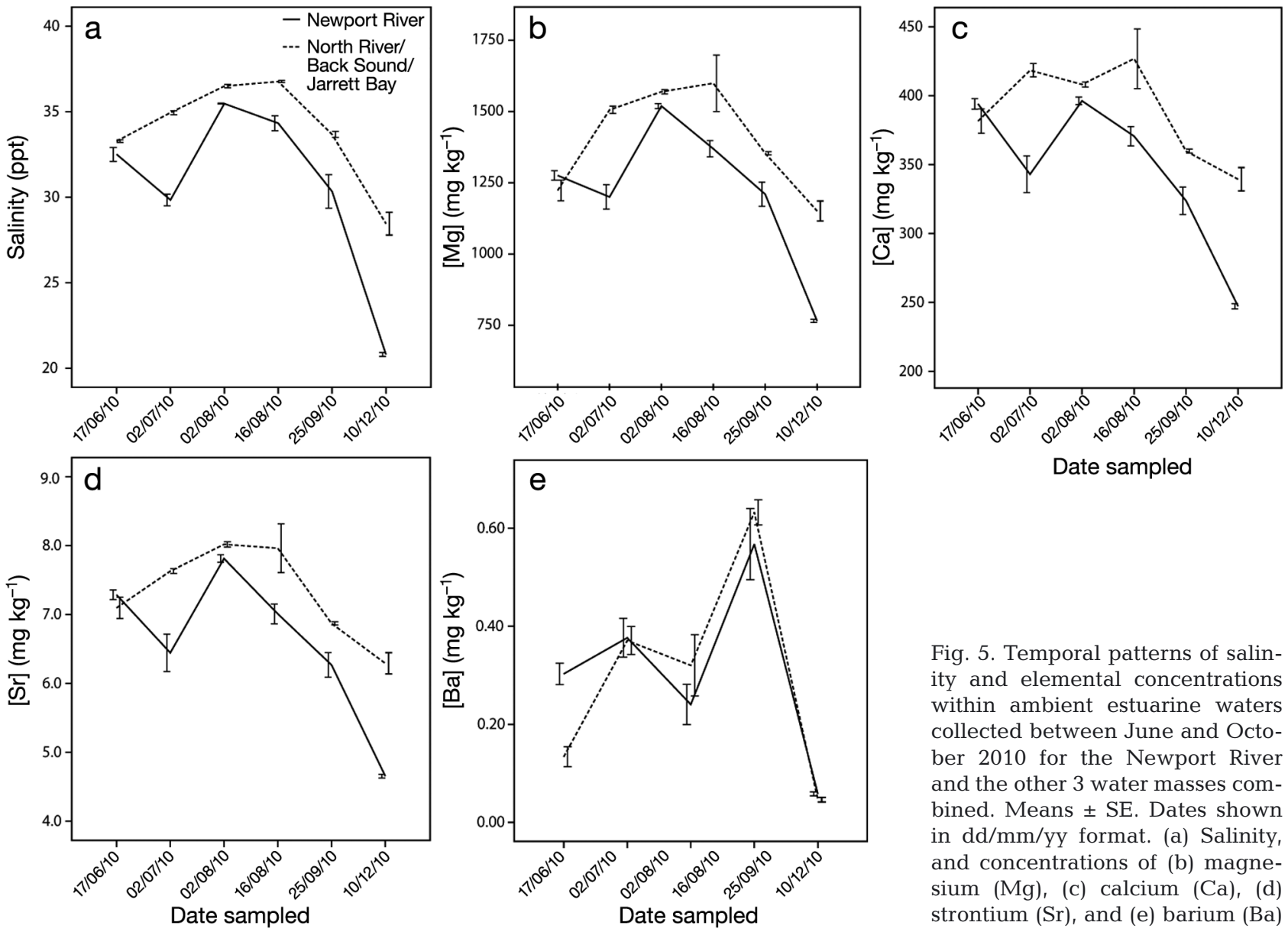

Fig. 5. Temporal patterns of salinity and elemental concentrations within ambient estuarine waters collected between June and October 2010 for the Newport River and the other 3 water masses combined. Means \pm SE. Dates shown in $\mathrm{dd} / \mathrm{mm} / \mathrm{yy}$ format. (a) Salinity, and concentrations of (b) magnesium (Mg), (c) calcium (Ca), (d) strontium (Sr), and (e) barium (Ba)

content of juvenile shell collected during October differed among locations despite an absence of significant differences in Ba concentration among estuarine waters (Fig. 5e). The analysis of the entire biomineral in solution could potentially explain this contradiction as it provided a cumulative signal generated over the entire juvenile phase that went undetected in individual water samples (Campana 1999, Becker et al. 2005).

There is also evidence to suggest that Ba may be associated with phytoplankton biomass, particularly diatoms. The demonstration of dissolved Ba being highly concentrated on diatom frustules via adsorption onto iron oxyhydroxides (Sternberg et al. 2005) prompted Thébault et al. (2009) to conclude that dissolved $\mathrm{Ba}$ associated with diatoms desorb in the bivalve gut due to low $\mathrm{pH}(<8)$ and absorb through the gut epithelium into internal fluids to be incorporated into shell material. Analysis of sampled estuarine waters occurred after a series of filtrations to remove particulate fractions while maintaining colloidal and dissolved fractions. Thus any $\mathrm{Ba}$ associ- ated with primary production via adsorptive processes could be entrained during filtration, thereby reducing estimates of dissolved Ba available in ambient estuarine waters. Future studies would benefit from the simultaneous analysis of filtered and unfiltered water to provide a more holistic interpretation of elemental species available for incorporation into molluscan biominerals.

Juvenile shell also exhibited significant differences in $\mathrm{Mg}$ concentration among water masses on both sampling dates. In estuarine waters, $\mathrm{Mg}$ is reported to behave conservatively along the salinity gradient (Stecher et al. 1996, Dorval et al. 2005a). This trend was supported in our study area as evidenced by consistently reduced concentrations in the Newport River compared to all other water masses of investigation (Figs. 5b \& 6a). Concentrations of $\mathrm{Mg}$ in hard clam juvenile shell collected during October parallel this observation, hinting that a relationship may exist between ambient $\mathrm{Mg}$ availability and incorporation into juvenile shell (Fig. 5b, Table 1). Work by Lorens \& Bender (1980) 

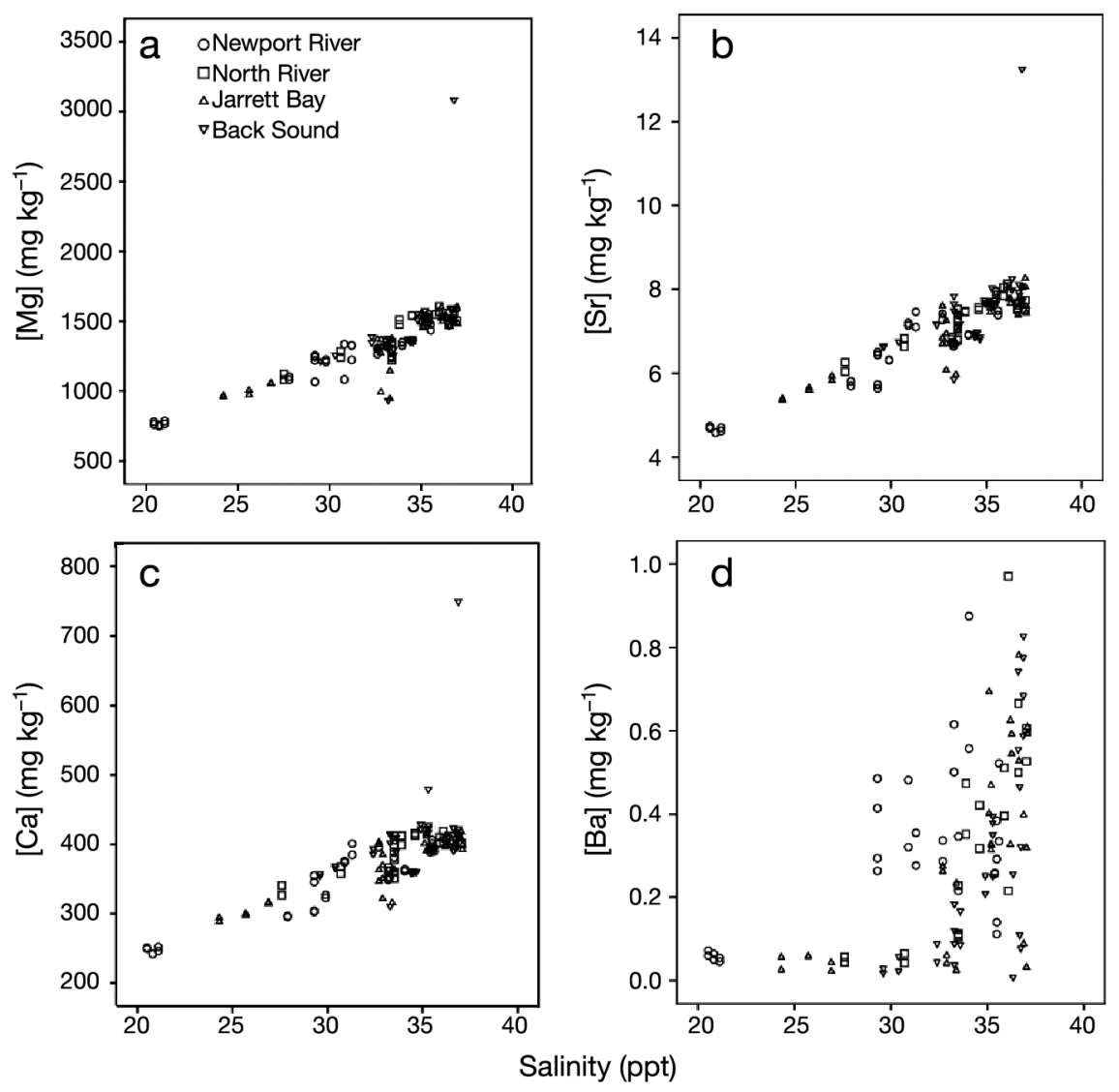

Fig. 6. Interaction between salinity and the concentrations of (a) magnesium (Mg), (b) strontium (Sr), (c) calcium (Ca), and (d) barium (Ba), grouped according to water mass of collection

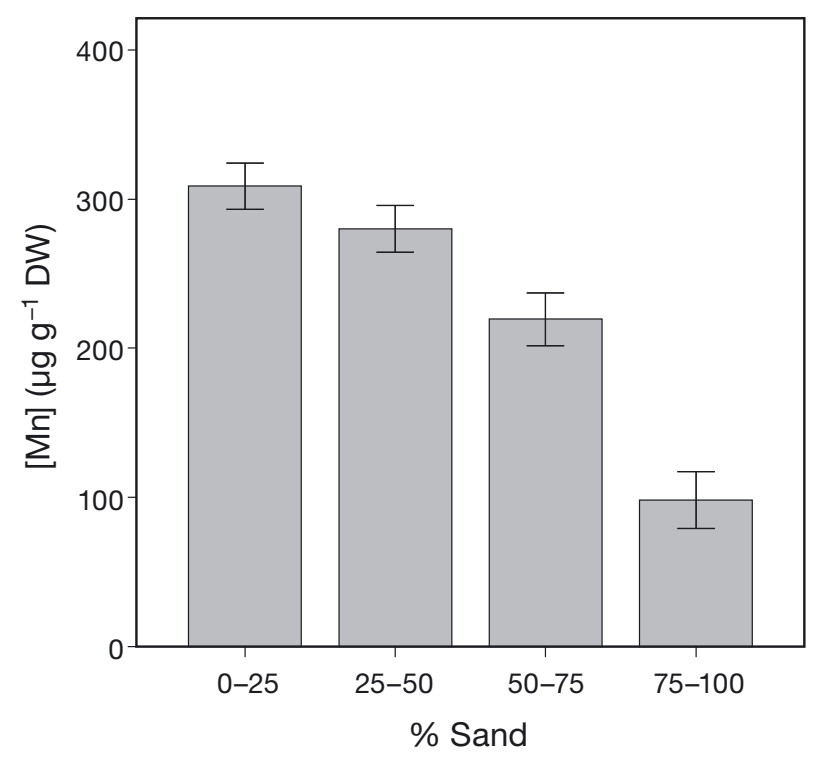

Fig. 7. Concentration of manganese (Mn) within sediments (dry weight, DW) sampled from the Neuse River Estuary containing different fractions of sand. Means \pm SE. Data from Riggs et al. (1991) supports this relationship by demonstrating a directly proportional relationship between $\mathrm{Mg}$ content of bivalve aragonite and the $\mathrm{Mg}$ content of the water in which it formed.

The elements $\mathrm{Ti}, \mathrm{Co}, \mathrm{Cu}, \mathrm{Zn}, \mathrm{Al}$, and $\mathrm{Pb}$ within juvenile clam shell differed among water masses during June sampling only (Table 1 ). DiBacco \& Levin (2000) used $\mathrm{Cu}$, $\mathrm{Zn}$, and $\mathrm{Al}$ to discriminate crab zoea collected from San Diego Bay. Similarly, Becker et al. $(2005,2007)$ used $\mathrm{Pb}$ to discriminate both mussel recruits and outplanted veligers from San Diego Bay. These authors postulate industrial and urban runoff as the primary factors influencing the availability of these elements. Laboratory experiments conducted by Zacherl et al. (2009) demonstrate a positive relationship between $\mathrm{Pb}$ concentrations in culture water and incorporation into juvenile and larval oyster shell and an absence of any such relationship with $\mathrm{Cu}$. The well-mixed nature of our study area coupled with differential land use patterns including non-point pollution from the adjacent municipalities of Morehead City and Beaufort and extensive agricultural development suggests that anthropogenic inputs may be influencing the availability and incorporation of metals into juvenile clam shell (Swearer et al. 2003).

Finally, Sr represents an element that did not differ within juvenile clam shell among sites during October despite consistently reduced concentrations within the Newport River compared to all other water masses (Fig 5d, Table 1). These findings are in agreement with other investigations concerning Sr incorporation into molluscan biominerals (Lloyd et al. 2008, Zumholz et al. 2007, Zacherl et al. 2009). Sr incorporation within abiogenic carbonate is highly influenced by precipitation rate (Lorens 1981, Morse \& Bender 1990). Additionally, work by Lorrain et al. (2005) demonstrates that kinetic effects strongly influence Sr incorporation into Pecten maximus shell. Similar kinetic effects could potentially explain the absence of any relationship between the Sr content juvenile hard clam carbonate and the $\mathrm{Sr}$ content within the estuarine waters in which it formed. 


\section{Temporal variation of elemental fingerprints}

Eleven minor and trace elements were present in juvenile clam shell on both sampling dates. Of these elements, $\mathrm{Ti}, \mathrm{Cu}, \mathrm{Zn}, \mathrm{Mg}, \mathrm{Mn}, \mathrm{Co}, \mathrm{Ni}, \mathrm{Mg}$ and $\mathrm{Pb}$ differed significantly between sampling dates. These differences are not unexpected given the dynamic nature of estuarine systems (Swearer et al. 2003). Work by Fodrie et al. (2011) demonstrated monthly and seasonal variation in the elemental composition of $\mathrm{Mg}, \mathrm{Cu}, \mathrm{Sr}, \mathrm{Mn}, \mathrm{Cd}, \mathrm{Pb}$, and $\mathrm{U}$ of juvenile shell from 2 species of Mytilus. Similarly, Dunphy et al. (2011) demonstrated seasonal variation regarding the $\mathrm{Ni}, \mathrm{Cu}$, and $\mathrm{Ba}$ content of juvenile green-lipped mussels Perna canaliculus. A combined DFA using clams from both sampling dates suggests that temporal differences in elemental composition confounded our signal as evidenced by a reduction in overall classification success (81.9\%) (Fig. 3c, Table 4). Importantly, Mn still explained the bulk of our among group variance $(89.9 \%)$ and only differed significantly $(\mathrm{p}<0.05)$ in the North River between sampling dates. Additionally, Mn within juvenile shell was consistently different among water masses on both sampling dates, suggesting that the primary component of our elemental signal is reproducible through time (Fig. 4a,b). However, given that DFA from individual sampling events yielded perfect classification success $(100 \%)$ of individual sampling sites, the collection of larval reference samples during seasonally elevated periods of dispersal could maximize the applicability of elemental fingerprinting to identify the natal origin of unknown recruits (Fig. 3a,b, Tables 2 \& 3). Ideally, a reference map of larval trace element signatures for individual water masses would be generated and monitored for intra- and inter-annual variability. Pending the stability of elemental signals encountered, it may be possible to collect a recruited hard clam, analyze the elemental composition of the PDI, then compare it to the reference map of known locations to potentially identify the natal origin and dispersal trajectory of an individual clam.

The incorporation of minor and trace elements into bivalve shell is strongly influenced by vital and kinetic effects (Stecher et al. 1996, Lorrain et al. 2005, Carré et al. 2006, Schöne 2008, Takesue et al. 2008). In North Carolina recruited hard clams can be assigned to spring or fall spawning events if they fall between 16 and $26 \mathrm{~mm}$ or below $15 \mathrm{~mm}$ length thresholds respectively (Peterson 2002). All sampled recruits were $<10 \mathrm{~mm}$ in length, allowing us to assume that they are representative of seasonal spawn- ing events. However, the growth of juvenile hard clams is highly variable and may be influenced by interactions within or among exogenous and endogenous factors (as reviewed by Carriker 2001). Within our study area growth of hard clams is highly influenced by both habitat type and genetic composition (Peterson \& Beal 1989). Given these factors, we can only assume that juvenile clams collected during October settled at some point during the reproductive season of 2010, while clams from June sampling settled at some point during the spring of 2011. To reduce the bias of exogenous factors on juvenile clam growth, samples were collected from similar habitat types (subtidal sand) in each water mass. However, accounting for genetic variation among sites is difficult given the planktonic duration of hard clam larvae $(\sim 11$ to $20 \mathrm{~d})$ and the well mixed nature of our study area (Leuttich et al. 1999, Carriker 2001). Given that juvenile clams collected during the spring were significantly larger $\left(t_{47}=-3.62, \mathrm{p}=0.001\right)$ than individuals collected during the fall, differences in shell growth could possibly have influenced rates of elemental incorporation between sampling dates.

The possibility that juvenile clams collected during October sampling could have settled at any point during 2010 also suggests that ontogenetic effects may be influencing elemental incorporation. Zacherl et al. (2009) investigated the influence of ontogeny on the elemental incorporation of multiple elements into oyster shell and demonstrated that $\mathrm{Mg}, \mathrm{Sr}$, and $\mathrm{Cu}$ exhibit ontogenetic effects. Specifically, Mg was elevated in settled individuals, while $\mathrm{Sr}$ and $\mathrm{Cu}$ were increased in the larval form. Additionally, $\mathrm{Cu}$ has been shown to exhibit a similar ontogenetic effect regarding assimilation into hard clam somatic tissue (Larsen 1979). These studies highlight that the extrapolation of elemental signals within juvenile carbonate to pelagic larvae must be taken with great care.

Our results are promising in that they demonstrate distinct elemental signals exist within juvenile hard clam shell that can be used to assign individuals to sites of collection at small spatial scales $(\sim 12 \mathrm{~km})$ within a well mixed estuarine-lagoonal system with high levels of success $(100 \%)$ during elevated periods of larval dispersal (Fig. 3a,b, Tables 2 \& 3). Future work will focus on 2 priorities: (1) Validation of our observed signal within the larval form by outplanting larvae through the secretion of the first larval shell PDI as per Becker et al. (2007). (2) Method development to analyze the retained larval shell PDI of recruited individuals using the microprobe assay laser ablation inductively coupled plasma mass spectrometry (LA-ICP-MS) without sampling underlying 
juvenile shell (see Strasser et al. 2007, Zacherl et al. 2009 for a detailed overview). These data could elucidate the influence of dispersal on the population dynamics of this species through the identification of subpopulations that may disproportionately supply larvae. From a management perspective these source populations would benefit the most from conservation and restoration efforts.

Acknowledgements. The authors thank the East Carolina University Department of Biology for financial support, D. R. Corbett for use of the ICP-OES, and M. Trube, G. Trube, L. Thompson, A. Madison, L. McKenna, B. McGlaughon, D. Zapf, A. Taylor and D. Daniels for field help. The authors also thank 2 anonymous reviewers for improving an earlier version of this manuscript.

\section{LITERATURE CITED}

Becker BJ, Fodrie FJ, McMillan PA, Levin LA (2005) Spatial and temporal variation in trace elemental fingerprints of mytilid mussel shells: a precursor to invertebrate larval tracking. Limnol Oceanogr 50:48-61

> Becker BJ, Levin LA, Fodrie JF, McMillan PA (2007) Complex larval connectivity patterns among marine invertebrate populations. Proc Natl Acad Sci USA 104: 3267-3272

> Campana SE (1999) Chemistry and composition of fish otoliths: pathways, mechanisms, and applications. Mar Ecol Prog Ser 188:263-297

> Campana SE, Chouinard GA, Hanson JM, Fréchet A, Brattey J (2000) Otolith elemental fingerprints as biological tracers of fish stocks. Fish Res 46:343-357

> Carré M, Bentaleb I, Bruguier O, Ordinola E, Barrett NT, Fontugne $M$ (2006) Calcification rate influence on the trace element concentrations in aragonitic bivalve shells: evidences and mechanisms. Geochim Cosmochim Acta 70:4906-4920

Carriker MR (2001) Embryogenesis and organogenesis of veligers and early juveniles. In: Kraeuter JN, Castagna M (eds) Biology of the hard clam. Elsevier Science BV, Amsterdam, p 77-116

> Coffey MF, Dehairs F, Collette O, Luther G, Church T, Jickells $\mathrm{T}$ (1997) The behaviour of dissolved barium in estuaries. Estuar Coast Shelf Sci 45:113-121

DiBacco C, Levin LA (2000) Development and application of elemental fingerprinting to track the dispersal of marine invertebrate larvae. Limnol Oceanogr 45:871-880

> Dorval E, Jones CM, Hannigan R (2005a) Chemistry of surface waters: distinguishing fine-scale differences in seagrass habitats of Chesapeake Bay. Limnol Oceanogr 50: 1073-1083

> Dorval E, Jones MC, Hannigan R, van Montfrans J (2005b) Can otolith chemistry be used for identifying essential seagrass habitats for juvenile spotted seatrout, Cynoscion nebulosus, in Chesapeake Bay? Mar Freshw Res 56:645-653

Dunphy BJ, Millet MA, Jeffs AG (2011) Elemental signatures in the shells of early juvenile green-lipped mussels (Perna canaliculus) and their potential use for larval tracking. Aquaculture 311:187-192
Elsdon TS, Gillanders BM (2004) Fish otolith chemistry influenced by exposure to multiple environmental factors. J Exp Mar Biol Ecol 313:269-284

Evans DW, Cutshall NH, Cross FA, Wolfe DA (1977) Manganese cycling in the Newport River estuary, North Carolina. Estuar Coast Mar Sci 5:71-80

> Fodrie FJ, Becker BJ, Levin LA, Gruenthal K, McMillan PA (2011) Connectivity clues from short-term variability in settlement and geochemical tags of mytilid mussels. J Sea Res 65:141-150

George DA, Hill PS, Milligan TG (2007) Flocculation, heavy metals $(\mathrm{Cu}, \mathrm{Pb}, \mathrm{Zn})$ and the sand-mud transition on the Adriatic continental shelf, Italy. Cont Shelf Res 27:475-488

Gillanders BM (2002) Temporal and spatial variability in elemental composition of otoliths: implications for determining stock identity and connectivity of populations. Can J Fish Aquat Sci 59:669-679

Gillanders BM, Kingsford MJ (1996) Elements in otoliths may elucidate the contribution of estuarine recruitment to sustaining coastal reef populations of a temperate reef fish. Mar Ecol Prog Ser 141:13-20

> Gillikin DP, Dehairs F, Lorrain A, Steenmans D, Baeyens W, André L (2006) Barium uptake into the shells of the common mussel (Mytilus edulis) and the potential for estuarine paleo-chemistry reconstruction. Geochim Cosmochim Acta 70:395-407

> Krause-Nehring J, Klügel A, Nehrke G, Brellochs B, Brey T (2011) Impact of sample pretreatment on the measured element concentrations in the bivalve Arctica islandica. Geochem Geophys Geosyst 12:Q07015

> Larsen PF (1979) The distribution of heavy metals in the hard clam, Mercenaria mercenaria, in the lower Chesapeake Bay region. Estuaries 2:1-8

Leuttich RA, Hench JL, Fulcher CW, Werner FE, Blanton BO, Churchill JH (1999) Barotropic tidal and wind-driven larval transport in the vicinity of a barrier island inlet. Fish Oceanogr 8:190-209

> Lloyd DC, Zacherl DC, Walker S, Paradis G, Sheehy M, Warner RR (2008) Egg source, temperature and culture seawater affect elemental signatures in Kelletia kelletii larval statoliths. Mar Ecol Prog Ser 353:115-130

> Lorens RB (1981) Sr, Cd, Mn, and Co distribution coefficients in calcite as a function of calcite precipitation rate. Geochim Cosmochim Acta 45:553-561

> Lorens RB, Bender ML (1980) The impact of solution chemistry on Mytilus edulis calcite and aragonite. Geochim Cosmochim Acta 44:1265-1278

> Lorrain A, Gillikin DP, Paulet YM, Chauvaud L, Le Mercier A, Navez J, André L (2005) Strong kinetic effects on Sr/ $\mathrm{Ca}$ ratios in the calcitic bivalve Pecten maximus. Geology 33:965-968

Manly BFJ (ed) (2005) Tests of significance with multivariate data. In: Multivariate statistical methods: a primer, 3rd edn. Chapman \& Hall, Boca Raton, FL

Mohan JA, Rulifson RA, Corbett RD, Halden NM (2012) Validation of oligohaline elemental otolith signatures of striped bass by use of in situ caging experiments and water chemistry. Mar Coast Fish 4:57-70

- Morris AW, Bale AJ, Howland RJM (1982) The dynamics of estuarine manganese cycling. Estuar Coast Shelf Sci 14: 175-192

Morrison JO, Brand U (1986) Geochemistry of recent marine invertebrates. Geosci Can 13:237-254

Morse JW, Bender ML (1990) Partition coefficients in calcite: examination of factors influencing the validity of experi- 
mental results and their application to natural systems. Chem Geol 82:265-277

Peterson $\mathrm{CH}$ (2002) Recruitment overfishing in a bivalve mollusc fishery: hard clams (Mercenaria mercenaria) in North Carolina. Can J Fish Aquat Sci 59:96-104

Peterson CH, Beal BF (1989) Bivalve growth and higher order interactions: importance of density, site, and time. Ecology 70:1390-1404

Peterson CH, Fegley SR (1986) Seasonal allocation of resources to growth of shell, soma, and gonads in Mercenaria mercenaria. Biol Bull 171:597-610

Riggs SR, Bray JT, Powers ER, Hamilton JC and others (1991) Heavy metals in organic rich muds of the Neuse River estuarine system. Albemarle-Pamlico Estuarine Study, Report 90-07. NC Department of Environment and Natural Resources, Raleigh, NC

Ruttenberg BI, Hamilton SL, Warner RR (2008) Spatial and temporal variation in the natal otolith chemistry of a Hawaiian reef fish: prospects for measuring population connectivity. Can J Fish Aquat Sci 65:1181-1192

Schöne BR (2008) The curse of physiology — challenges and opportunities in the interpretation of geochemical data from mollusk shells. Geo-Mar Lett 28:269-285

Stecher HA, Krantz DE, Lord CJ, Luther GW, Bock KW (1996) Profiles of strontium and barium in Mercenaria mercenaria and Spisula solidissima shells. Geochim Cosmochim Acta 60:3445-3456

Sternberg E, Tang D, Ho TY, Jeandel C, Morel FMM (2005) Barium uptake and adsorption in diatoms. Geochim Cosmochim Acta 69:2745-2752

Strasser CA, Thorrold SR, Starczak VR, Mullineaux LS (2007) Laser ablation ICP-MS analysis of larval shell in softshell clams (Mya arenaria) poses challenges for natural tag studies. Limnol Oceanogr Methods 5:241-249

Swearer SE, Forrester GE, Steele MA, Brooks AJ, Lea DW (2003) Spatio-temporal and interspecific variation in otolith trace-elemental fingerprints in a temperate estuarine fish assemblage. Estuar Coast Shelf Sci 56: 1111-1123

Takesue RK, Bacon CR, Thompson JK (2008) Influences of organic matter and calcification rate on trace elements in

Editorial responsibility: Inna Sokolova,

Charlotte, North Carolina, USA aragonitic estuarine bivalve shells. Geochim Cosmochim Acta 72:5431-5445

Thébault J, Chauvaud L, L'Helguen S, Clavier J, Barats A, Jacquet S, Pécheyran C, Amouroux D (2009) Barium and molybdenum records in bivalve shells: geochemical proxies for phytoplankton dynamics in coastal environments? Limnol Oceanogr 54:1002-1014

- Thorrold SR, Shuttleworth S (2000) In situ analysis of trace elements and isotope ratios in fish otoliths using laser ablation sector field inductively coupled plasma mass spectrometry. Can J Fish Aquat Sci 57:1232-1242

Thorrold SR, Jones GP, Hellberg ME, Burton RS and others (2002) Quantifying larval retention and connectivity in marine populations with artificial and natural markers. Bull Mar Sci 70:291-308

Thorrold SR, Zacherl DC, Levin LA (2007) Population connectivity and larval dispersal using geochemical signatures in calcified structures. Oceanography 20:80-89

Thorson G (1950) Reproductive and larval ecology of marine bottom invertebrates. Biol Rev Camb Philos Soc 25:1-45

> Vander Putten E, Dehairs F, Keppens E, Baeyens W (2000) High resolution distribution of trace elements in the calcite shell layer of modern Mytilus edulis: environmental and biological controls. Geochim Cosmochim Acta 64: 997-1011

- Zacherl DC (2005) Spatial and temporal variation in statolith and protoconch trace elements as natural tags to track larval dispersal. Mar Ecol Prog Ser 290:145-163

Zacherl DC, Paradis G, Lea DW (2003) Barium and strontium uptake into larval protoconchs and statoliths of the marine neogastropod Kelletia kelletii. Geochim Cosmochim Acta 67:4091-4099

Zacherl DC, Morgan SG, Swearer SE, Warner RW (2009) A shell of its former self: Can Ostrea lurida Carpenter 1864 larval shells reveal information about a recruit's birth location? J Shellfish Res 28:23-32

Zumholz K, Hansteen TH, Piatkowski U, Croot PL (2007) Influence of temperature and salinity on the trace element incorporation into statoliths of the common cuttlefish (Sepia officinalis). Mar Biol 151:1321-1330

Submitted: December 28, 2011; Accepted: June 21, 2012

Proofs received from author(s): September 17, 2012 